\title{
Article \\ Cocoa (Theobroma cacao L.) Seed-Derived Peptides Reduce Blood Pressure by Interacting with the Catalytic Site of the Angiotensin-Converting Enzyme
}

\author{
Luis Jorge Coronado-Cáceres ${ }^{1}{ }^{(0}$, Blanca Hernández-Ledesma ${ }^{2, *}{ }^{\circledR}$, Luis Mojica ${ }^{1}\left(\mathbb{D}\right.$, Lucía Quevedo-Corona ${ }^{3}{ }^{(}$, \\ Griselda Rabadán-Chávez ${ }^{1}$, Gustavo Adolfo Castillo-Herrera ${ }^{1}\left[\right.$ (1) and Eugenia Lugo Cervantes ${ }^{1, *}$ \\ 1 Unidad de Tecnología Alimentaria, Centro de Investigación y Asistencia en Tecnología y Diseño del Estado \\ de Jalisco, Guadalajara 44270, Mexico; lucoronado@ciatej.mx (L.J.C.-C.); Imojica@ciatej.mx (L.M.); \\ gris.rab@gmail.com (G.R.-C.); gcastillo@ciatej.mx (G.A.C.-H.) \\ 2 Instituto de Investigación en Ciencias de la Alimentación (CIAL, CSIC-UAM, CEI UAM+CSIC), \\ 28049 Madrid, Spain \\ 3 Departamento de Fisiología, Escuela Nacional de Ciencias Biológicas, Instituto Politécnico Nacional, \\ Wilfrido Massieu s/n Esq. Manuel I. Stampa, Col. Unidad Profesional Adolfo López Mateos, \\ Mexico 07738, Mexico; quevedocorona@hotmail.com \\ check for \\ updates \\ * Correspondence: b.hernandez@csic.es (B.H.-L.); elugo@ciatej.mx (E.L.-C.)
}

Citation: Coronado-Cáceres, L.J.; Hernández-Ledesma, B.; Mojica, L.; Quevedo-Corona, L.;

Rabadán-Chávez, G.;

Castillo-Herrera, G.A.; Lugo

Cervantes, E. Cocoa (Theobroma cacao

L.) Seed-Derived Peptides Reduce

Blood Pressure by Interacting with

the Catalytic Site of the

Angiotensin-Converting Enzyme.

Foods 2021, 10, 2340. https:/ / doi.org/

$10.3390 /$ foods 10102340

Academic Editors:

Sergio Montserrat-de la Paz and

María Del Carmen Millán-Linares

Received: 9 September 2021

Accepted: 28 September 2021

Published: 30 September 2021

Publisher's Note: MDPI stays neutra with regard to jurisdictional claims in published maps and institutional affiliations.

Copyright: (c) 2021 by the authors. Licensee MDPI, Basel, Switzerland. This article is an open access article distributed under the terms and conditions of the Creative Commons Attribution (CC BY) license (https:/ / creativecommons.org/licenses/by/ $4.0 /)$.

\begin{abstract}
This study aimed at determining the effect of cocoa proteins (CP) on the blood pressure, using in silico, in vitro and in vivo approaches. The in silico assay showed 26 Criollo cocoa peptides with alignment in the Blast ${ }^{\circledR}$ analysis. Peptide sequences ranged from 6 to 16 amino acids, with molecular weight ranging from 560.31 to $1548.76 \mathrm{Da}$. The peptide sequences LSPGGAAV, TSVSGAGGPGAGR, and TLGNPAAAGPF showed the highest theoretical affinity with $-8.6,-5.0$, and $-10.2 \mathrm{kcal} / \mathrm{mol}$, for the angiotensin-converting enzyme (ACE), renin, and angiotensin II type 1 receptor $\left(\mathrm{AT}_{1}-\mathrm{R}\right)$, respectively. The Criollo $\mathrm{CP}$ hydrolysates $(\mathrm{CPH})$ presented in vitro $\mathrm{ACE}$ inhibitory activity with an $\mathrm{IC}_{50}$ value of $0.49 \mathrm{mg} / \mathrm{mL}$. Furthermore, the orogastric administration of $150 \mathrm{mg} \mathrm{CP} / \mathrm{kg} /$ day in rats fed a high-fat (HF) diet ( $\mathrm{HF}+\mathrm{CP}$ group) showed a significant decrease in systolic blood pressure (SBP) by $5 \%(p<0.001)$ and diastolic blood pressure (DBP) by $7 \%(p<0.001)$ compared with the HF group. The human equivalent dose (HED) of CP for an adult $(60 \mathrm{~kg})$ is $1.45 \mathrm{~g}$ per day. These results suggest that the consumption of $\mathrm{CP}$ could reduce blood pressure by blocking $\mathrm{ACE}$, and could be used as an ingredient in the elaboration of antihypertensive functional foods.
\end{abstract}

Keywords: antihypertensive; angiotensin-converting enzyme; proteins; bioactive peptides; molecular docking; Theobroma cacao L.

\section{Introduction}

According to the World Health Organization (WHO), in 2016, almost 2 billion adults were overweight and 600 million were obese. Obesity is a risk factor for developing noncommunicable diseases (NCDs) such as cardiovascular disease, type 2 diabetes mellitus, neurodegenerative diseases and cancer [1]. NCDs are the leading cause of mortality worldwide, with an estimated 39.5 million deaths per year (72.3\% of total death in 2016$)$. The largest number of deaths for NCDs was caused by cardiovascular diseases (17.6 million). Global, deaths from cardiovascular disease increased by 14.5\% between 2006 and 2016 [2].

Hypertension affects around 1.4 billion people globally [3,4] and represents the principal risk factor for ischemic heart disease and cerebrovascular disease (stroke). Ischemic heart disease and stroke accounted for more than $85 \%$ of cardiovascular disease deaths. The blood pressure is regulated by the renin-angiotensin system (RAS), integrated by enzymes renin and the angiotensin-converting enzyme (ACE). The renin is a $37 \mathrm{kDa}$ protein that hydrolyse a $55 \mathrm{kDa}$ hepatic protein (angiotensinogen) to produce an inactive decapeptide called angiotensin I (DRVYIHPFHL) [5]. ACE acts converting angiotensin I into angiotensin 
II (a potent vasoconstrictor) by removing the C-terminal dipeptide HL [5]. The inhibition of renin and ACE in the RAS pathway is considered an important therapeutic strategy in treating hypertension $[3,6]$ which is a controllable risk factor for cardiovascular diseases. $\mathrm{ACE}$ is the molecular target of antihypertensive drugs such as Captopril, Lisinopril, Benazepril, and Zofenopril [7-9]. However, because of the side effects associated with the use of these drugs, the interest has focused on the search of antihypertensive compounds from natural sources [10]. Among these compounds, those from proteinaceous nature are the most promising. Peptides from different food sources such as sesame and hemp seeds, corn, spinach, egg white proteins, rapeseed, meat, flaxseed, insects, birdseed, and amaranth seed have been characterised by their antihypertensive properties [11-13].

The Criollo cocoa (Theobroma cacao L.) is a native plant to Central America, mainly Mexico's southern and southeastern regions [14]. The cocoa seeds used for the manufacture of chocolate are of great economic importance worldwide [15]. The polyphenols and flavonoids of cocoa (PFC) have been considered the main responsible for the blood pressure reducing effects associated with cocoa consumption. The impact of PFC has been observed in both in vitro [16], and in vivo assays $[17,18]$. However, the existing data on the effect of cocoa proteins (CP) against hypertension is limited. Autolysates of Malaysian cocoa (unknown variety) have been demonstrated to inhibit ACE, analyzed by an in vitro assay [19]. However, to date, no animal models have been carried out to confirm the in vivo effects of CP. Thus, the objective of this work was to determine the effect of $\mathrm{CP}$ on blood pressure in an obesity-induced by diet rat model, and to elucidate the potential mechanism of action using in silico and in vitro models.

\section{Materials and Methods}

\subsection{Materials}

Cocoa seeds of the Criollo variety called "Carmelo" were obtained from the Municipality of Tuxtla Chico (Chiapas, Mexico). Six-week-old male Wistar rats (180 $\pm 5 \mathrm{~g}$ of body weight) were acquired from the Animal House of Autonomous Metropolitan University, Xochimilco Campus (Ciudad de Mexico, Mexico). Membrane was from Biotech CE 0.1-0.5 kDa MWCO (131060; Spectrum ${ }^{\mathrm{TM}}$ Laboratories, Inc., Rancho Dominguez, CA, USA). ACEI Activity Assay Fluorometric Kit (CS0002) was purchased from Sigma-Aldrich ${ }^{\mathrm{TM}}$, (St. Louis, MO, USA).

\subsection{Protein Extraction from Theobroma cacao $L$.}

The coat and the mucilage of pods-derived seeds were removed, seeds were lyophilized and ground, and the flour was defatted in three phases: flour was dissolved in hexane:chloroform $(2: 1, v / v)$ at ratio 1:15 $(w / v)$, magnetically stirred for $90 \mathrm{~min}$, and centrifuged at $4700 \times \mathrm{g}$ for $20 \mathrm{~min}$ at $4{ }^{\circ} \mathrm{C}$ [20]. The pellet was collected and dried in the extraction hood. The dry pellet was used to obtain the acetone dry powder (AcDP) [21]. AcDP was prepared to prevent polyphenols from disturbing analysis and avoiding the generation of false positives. The polyphenols were extracted three times with an $80 \%(v / v)$ cold aqueous acetone containing $5 \mathrm{mM}$ sodium ascorbate; subsequently, with $70 \%(v / v)$ cold aqueous acetone; and finally, the residual water was removed from acetone pellet by dehydration with $100 \%$ cold acetone [21,22]. Each time, 20 min-magnetic stirring at $4{ }^{\circ} \mathrm{C}$ followed by centrifugation $\left(15,000 \times g\right.$ for $15 \mathrm{~min}$ at $\left.4{ }^{\circ} \mathrm{C}\right)$ were carried out.

The CP were extracted following the protocols described by Voigt and coworkers [21] and Preza and coworkers [22], with some modifications, using three magnetic stirring steps $\left(20 \mathrm{~min}\right.$ at $\left.4{ }^{\circ} \mathrm{C}\right)$ with the following buffers at a ratio of 1:10 $(w / v)$ to extract the different protein fractions: albumins (water-soluble) (10 mM Tris- $\mathrm{HCl}$ containing $2 \mathrm{mM}$ EDTA, pH 7.5); globulins (salt-soluble) $(0.5 \mathrm{M} \mathrm{NaCl}$ containing $2 \mathrm{mM}$ EDTA and $10 \mathrm{mM}$ Tris- $\mathrm{HCl}, \mathrm{pH}$ 7.5); prolamins (aqueous isopropanol-soluble); and glutenins (alkali-proteins) $(0.1 \mathrm{~N} \mathrm{NaOH})$. After each step, samples were centrifuged at $15,000 \times g$ for $15 \mathrm{~min}$ at $4{ }^{\circ} \mathrm{C}$, and supernatants were precipitated using $6 \mathrm{~N} \mathrm{HCl}$ (pH 3.4) followed by centrifugation at $20,000 \times g$ for $20 \mathrm{~min}$ at $4{ }^{\circ} \mathrm{C}$. The collected pellet was lyophilized for further uses. The 
protein concentration of $\mathrm{CP}$ was determined by the Lowry method using bovine serum albumin (BSA) as standard [23]. The protein content of the sample was $81 \%$.

\subsection{Sodium Dodecyl Sulfate-Polyacrylamide Gel Electrophoresis (SDS-PAGE)}

Electrophoresis (SDS-PAGE) was performed in the Mini-PROTEAN system (Bio-Rad, Hercules, CA, USA), using $4 \%$ polyacrylamide stacking gels and $12.0 \%$ polyacrylamide resolving gels in reducing conditions and standard Tris-glycine buffers [24]. The image was obtained using a Gel Doc Documentation System (Gel Doc ${ }^{\mathrm{TM}} \mathrm{XR}+$ System, Bio-Rad Laboratories Inc., Hercules, CA, USA).

\subsection{Simulated Gastrointestinal Digestion}

The procedure described by Mojica and coworkers [25] was followed to simulate gastrointestinal digestion of $\mathrm{CP}$. Briefly, the sequential digestion of $\mathrm{CP}$ (dissolved in water at a ratio $1: 20 w / v)$ was performed with pepsin (enzyme/substrate ratio of 1:20 (w/w), $\mathrm{pH}$ $2.0,2 \mathrm{~h}$ ) and pancreatin (enzyme / substrate ratio of $1: 20(w / w), \mathrm{pH} 7.5,2 \mathrm{~h}$ ) at $37^{\circ} \mathrm{C}$. The enzymes were inactivated by heating at $75^{\circ} \mathrm{C}$ for $20 \mathrm{~min}$, and the resulting $\mathrm{CP}$ hydrolyzates $(\mathrm{CPH})$ were centrifuged at $20,000 \times \mathrm{g}$ for $15 \mathrm{~min}$ at $4{ }^{\circ} \mathrm{C}$, dialyzed using 100 to $500 \mathrm{Da}$ molecular weight cut off membranes, freeze-dried, and stored at $-20^{\circ} \mathrm{C}$ until analysis.

\subsection{Characterization of the Peptides and Sequence Identification}

The freeze-dried CPH were analyzed by liquid chromatography (LC) coupled to tandem mass spectrometry (LC-ESI-MS/MS), using the methodology of Souza Rocha [26] with some modifications, a Q-tof Ultima mass spectrometer 175 (Waters Corp., Milford, MA, USA), equipped with an Alliance ${ }^{\circledR} 2795$ HPLC system (Waters Corp.). Elution was performed by using a mobile phase composed of solvent $\mathrm{A}\left(95 \% \mathrm{H}_{2} \mathrm{O}, 5 \%\right.$ acetonitrile $\mathrm{ACN}$, and $0.1 \%$ formic acid) and solvent $\mathrm{B}\left(95 \% \mathrm{ACN}, 5 \% \mathrm{H}_{2} \mathrm{O}\right.$, and $0.1 \%$ formic acid) at a flow rate of $400 \mu \mathrm{L} / \mathrm{min}$. The linear gradient used was $0 \mathrm{~min}, 100 \% \mathrm{~A} ; 2 \mathrm{~min}, 90 \% \mathrm{~A}$; $6 \mathrm{~min}, 60 \% \mathrm{~A} ; 10 \mathrm{~min}, 0 \% \mathrm{~A} ; 12 \mathrm{~min}, 0 \% \mathrm{~A} ; 12.10 \mathrm{~min}, 100 \% \mathrm{~A} ; 15 \mathrm{~min}, 100 \% \mathrm{~A}$, and the temperature of the analysis was $20^{\circ} \mathrm{C}$. Using a positive ion electrospray mode (+ESI), the analysis on the Q-tof was carried out in V-mode with an instrument resolution ranged from 9000 to 10,000 based on full width at half maximum, with a flow rate of $20 \mu \mathrm{L} / \mathrm{min}$. The source and desolvation temperatures were set at $80^{\circ} \mathrm{C}$ and $250{ }^{\circ} \mathrm{C}$, respectively. The Q-tof was operated at a capillary voltage of $3.5 \mathrm{kV}$ and a cone voltage of $35 \mathrm{~V}$. The final detector was a microchannel plate with high sensitivity. The control of the instruments and the data processing was carried out with the MassLynx 4.1V software (Waters Corp.). Confirmation of peptides sequence was performed using the BLAST ${ }^{\circledR}$ tool (http:/ / www.blast.ncbi.nlm. nih.gov / Blast.cgi, accessed on 24 March 2021) [27].

\subsection{Biological Potential and Molecular Docking of Peptides from T. cocoa}

The biological potential of cocoa peptides was studied employing the BIOPEP-UWM database (http://www.uwm.edu.pl/biochemia/index.php/pl/biopep, accessed on 25 March 2021) [28]. The in silico biological potential of peptide sequences was evaluated based on the occurrence frequency of the fragments (amino acids) defined with the equation:

$$
\mathrm{A}=[\mathrm{a} / \mathrm{N}] ;
$$

where " $\mathrm{a}$ " is the number of fragments with given activity in a sequence; "N" is the number of amino acid residues of protein/peptide.

Using the following steps: in the BIOPEP-UWM database portal; select "Bioactive Peptides"; "ANALYSIS"; "CALCULATIONS"; "FOR YOUR SEQUENCE"; Paste the sequence; "Report". The peptides were designed and modeled using the 3D MarvinSketch program (Version 17.10, 2017, ChemAxon Lts, Záhony, Budapest, Hungary).

The crystal structures of human ACE-complex (PDB: 1O8A) [29], renin (PDB: ID 2V0Z), and $\mathrm{AT}_{1}-\mathrm{R}$ (PDB: ID 4YAY) were acquired from the Protein Data Bank (http:// www.rcsb.org/, accessed on 29 March 2021). Molecular docking methodology was used 
following Pan and Cao protocol [30] with some modifications. The best-ranked docking pose of the peptide in the active site of $\mathrm{ACE}$, renin, and $\mathrm{AT}_{1}-\mathrm{R}$ was obtained according to the scores and binding-energy value. Hydrogen atoms, solvation parameters, and atomic charge were added with the help of AutoDockTools vina 4.5 [31], with a grid of $30 \times 30$ $\times 30 \AA$, and a radius of $1 \AA$. Peptide-enzyme interactions were revised, and the potential type of interactions was shown with the Discovery Studio 2019 Client viewer (Accelrys Software Inc., San Diego, CA, USA).

\subsection{Angiotensin-Converting Enzyme (ACE) Inhibitory Activity}

The ACEI Activity Assay test contained a synthetic fluorogenic peptide as the substrate, and the resulting fluorescence was proportional to ACE activity [32,33]. Briefly, all reagents were diluted in the assay buffer, according to the manufacturer's instructions. A volume of $10 \mu \mathrm{L}$ of assay buffer (control) or $\mathrm{CPH}$ (at six different concentrations prepared in assay buffer) was mixed with $40 \mu \mathrm{L}$ of ACE. Subsequently, $50 \mu \mathrm{L}$ of fluorogenic substrate warmed to $37^{\circ} \mathrm{C}$ were added to experimental, control and blank sample wells, and the reaction was carried out at $37^{\circ} \mathrm{C}$ [32]. ACE inhibitory activity was measured using a fluorescence plate reader (Tecan Infinite M200 PRO, Salzburg, Austria), with excitation and emission wavelengths of 320 and $405 \mathrm{~nm}$, respectively. The \% ACE inhibition was calculated using the formula:

$$
\text { ACE inhibitory activity }(\%)=100 \times[((\mathrm{FC}-\mathrm{FB})-(\mathrm{FS}-\mathrm{FBs})) /(\mathrm{FC}-\mathrm{FB})]
$$

where FC (Control): Fluorescence emitted after the action of ACE on the substrate in the absence of inhibitor; FS (Sample): Fluorescence emitted after the action of ACE on the substrate in the presence of inhibitor sample. FB (Blank): Fluorescence emitted by the substrate. FBs (Blank sample): Fluorescence emitted by the substrate and the sample [34]. The $\mathrm{IC}_{50}$ was determined GraphPad Prism version 8.0.0 (GraphPad Software, San Diego, California USA, www.graphpad.com, accessed on 5-9 April 2021) by nonlinear regression of ACE inhibition (\%) caused by six different concentrations of $\mathrm{CPH}$.

\subsection{Animal Assay}

Obesity-induced six-week-old male Wistar rats were maintained under controlled conditions of humidity $(40-60 \%)$ and temperature $\left(22 \pm 2{ }^{\circ} \mathrm{C}\right)$, with $12 \mathrm{~h}$ dark $/ 12 \mathrm{~h} \mathrm{light}$ cycles. The rats were acclimatized for one week with unlimited access to food and water. A total of 21 rats were used and randomly divided into three dietary groups ( $n=7$ per group) as follows [20,35]: Standard Diet (STD group, $3.1 \mathrm{kcal} / \mathrm{g}$ ) (TD.05230; Teklad Global Harlan Laboratories, Inc., Madison, WI, USA), High-Fat diet (HF group, $4.5 \mathrm{kcal} / \mathrm{g}$ ) (TD.88137; Teklad Global Harlan Laboratories, Inc.), and HF-diet, supplemented with $150 \mathrm{mg} \mathrm{CP} / \mathrm{kg}$ /day through orogastric administration once daily ( $\mathrm{HF}+\mathrm{CP}$ group). The experimental period was 8 weeks. All animals were fed ad libitum with free access to water during the experimental period ( 8 weeks). The use of male Wistar rats was approved by the Ethics and Research Committee of the National School of Biological Sciences of the National Polytechnic Institute from Mexico [18,20,35,36].

\subsection{Blood Pressure Measurement}

Blood pressure measurements were carried out at a temperature of $36{ }^{\circ} \mathrm{C}$ in a noisefree environment by the tail-cuff method, using a computerized blood pressure system (IITC; Life Science Instruments, Woodland Hills, CA, USA). Three readings were taken consecutively on conscious rats at day 0 , and after eight weeks of treatment, and the average was calculated and taken as a final reading for systolic blood pressure (SBP), diastolic blood pressure (DBP), mean blood pressure (MBP), and heart rate (HR) $[18,36]$.

\subsection{Calculation of Human Equivalent Doses (HED)}

The animal dose should not be extrapolated to a human equivalent dose (HED) by a simple conversion based on body weight. For the more appropriate conversion of drug 
doses from animal to human studies, it is suggested the use of the Body Surface Area (BSA) normalization method [37] using the formula:

$\operatorname{HED}(\mathrm{mg} / \mathrm{kg})=$ Animal doses $(\mathrm{mg} / \mathrm{kg}) \times\left[\right.$ Animal $\mathrm{K}_{\mathrm{m}}(6$ for rat $) /$ Human $\mathrm{K}_{\mathrm{m}}(37$ for human of $\left.60 \mathrm{~kg})\right]$

where the $\mathrm{K}_{\mathrm{m}}$ factor is body weight $(\mathrm{kg})$ divided by BSA $\left(\mathrm{m}^{2}\right)$, and it is used to convert the $\mathrm{mg} / \mathrm{kg}$ dose used in a study to an $\mathrm{mg} / \mathrm{m}^{2}$ dose. Values-based on data from the Food and Drug Administration (FDA) [37,38].

\subsection{Statistical Analysis}

Data are expressed as mean values \pm standard error of the mean (SEM). All data were tested for normality and equality of variance using the Shapiro-Wilks and Levene's tests. One-way ANOVA was conducted, followed by the Holm-Sidak test (SigmaPlot 12.0 from SYSTAT Software, San Jose, CA, USA) for multiple comparisons in all quantitative variables. A value of $p<0.05$ represented a significant difference. Figure constructions were performed using GraphPad Prism ver. 6.01 (GraphPad Software, San Diego, CA, USA) [20].

\section{Results}

\subsection{Protein Fractions and Identification of Criollo cocoa Peptides}

The study of the CP profiles was performed SDS-PAGE. In Figure 1, the profiles of soluble $\mathrm{CP}$ were observed, corresponding to the fractions of water-soluble protein (albumin), salt-soluble protein (globulin or vicilin), isopropanol-soluble protein (prolamin), and alkali-soluble protein (glutelin). The concentration of soluble proteins of Criollo cocoa is shown in Table 1. The fractions with the highest protein concentration were glutelins > albumin > globulins, while the low concentration was found in the prolamine fraction that was not used for the following assays.

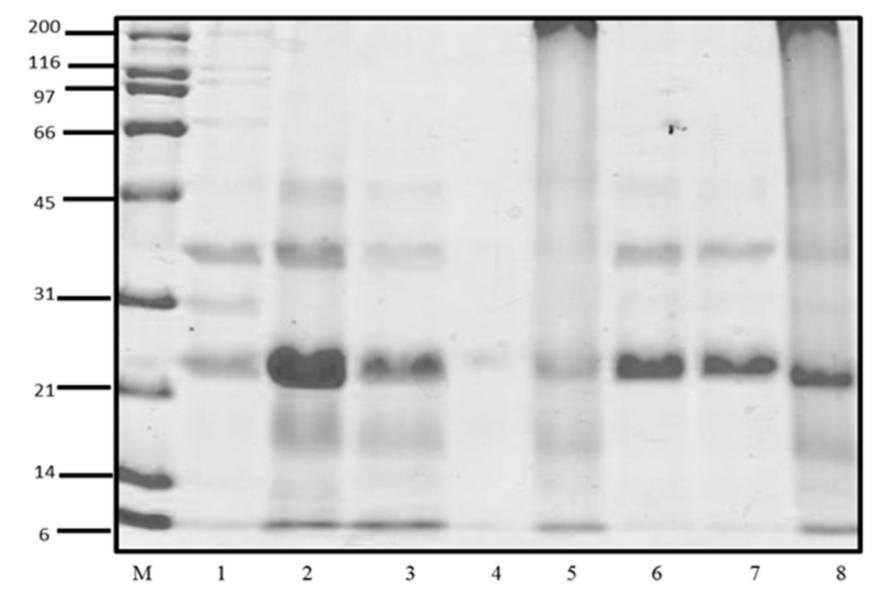

Figure 1. SDS-PAGE profiles of cacao protein (CP) fractions. $\mathrm{M})$ : molecular weight standard; 1: Albumin (Previous AcDP); 2: Albumins (AcDP); 3: Globulins (AcDP); 4: Prolamines (AcDP); 5: Glutelins (AcDP); 6: Total protein ( $\mathrm{pH} 8.0)$; 7: Total protein (10 $\mathrm{mM}$ Tris $\mathrm{pH}, 7.5)$; 8: Total protein (0.1 M NaOH). 
Table 1. Concentration and percentage of T. cocoa proteins obtained without and with AcDP.

\begin{tabular}{|c|c|c|c|c|}
\hline \multirow{2}{*}{ Protein Type } & \multicolumn{2}{|c|}{ Fresh Cocoa Seed (Previous AcDP) } & \multicolumn{2}{|c|}{ AcDP } \\
\hline & $\mathrm{mg} / \mathrm{g}$ & $\%$ & $\mathrm{mg} / \mathrm{g}$ & $\%$ \\
\hline Albumin & $7.85^{\mathrm{a}} \pm 0.91$ & 28.83 & $6.26^{b} \pm 0.78$ & 18.35 \\
\hline Globulin & $0.46^{b} \pm 0.43$ & 1.7 & $2.46^{\mathrm{a}} \pm 0.25$ & 7.22 \\
\hline Prolamin & \multicolumn{2}{|c|}{ NA } & $0.01 \pm 0.03$ & 0.02 \\
\hline \multirow[t]{2}{*}{ Glutelin } & $18.92^{\mathrm{b}} \pm 0.85$ & 69.46 & $25.38^{a} \pm 0.52$ & 74.41 \\
\hline & \multicolumn{2}{|c|}{$\mathrm{mg} / \mathrm{g}$} & \multicolumn{2}{|c|}{$\mathrm{mg} / \mathrm{g}$} \\
\hline TP pH 7.8 & \multicolumn{2}{|c|}{ NA } & \multicolumn{2}{|c|}{$2.94 \pm 0.51$} \\
\hline $\mathrm{TP}$ pH 8 & \multicolumn{2}{|c|}{ NA } & \multicolumn{2}{|c|}{$3.69 \pm 0.48$} \\
\hline TP $0.1 \mathrm{M} \mathrm{NaOH}$ & \multicolumn{2}{|c|}{ NA } & \multicolumn{2}{|c|}{$21.91 \pm 1.46$} \\
\hline
\end{tabular}

AcDP (acetone dry powder). ${ }^{\mathrm{a}, \mathrm{b}}$ indicate significantly different values $(p<0.05)$. Data are expressed as the mean of the results of two experiments realized by duplicate \pm SEM. NA: not analysed; TP: total protein.

Once collected, the water-soluble criollo CP were hydrolyzed and sequenced. In the chromatographic analysis, 55 peptide sequences were obtained, of which 26 were matched with the BLAST analysis. The peptide sequences presented molecular weights ranging from 560.31 to $1548.76 \mathrm{Da}$. Additionally, the biological potential of the cocoa peptide sequences was simulated using the BIOPEP-UWM database. The most common activities found were the dipeptidyl peptidase IV (DPP-IV) inhibitory activity related to diabetes, and the ACE and renin inhibitory activity and antithrombotic effects associated with cardiovascular diseases. Lower frequency of matched peptides corresponded to DPPIII inhibitory, antioxidant, chemotactic, anti-amnestic, and alpha-glucosidase inhibitory activities (Table 2).

Table 2. Peptide sequence of Criollo cocoa obtained from in vitro hydrolysis.

\begin{tabular}{|c|c|c|c|c|c|c|}
\hline Sequence & MW & Net Charge & $\begin{array}{l}\text { Isoelectric } \\
\text { Point }\end{array}$ & $\begin{array}{l}\text { Hydrophobicity } \\
\text { (Kcal/mol) }\end{array}$ & Biological Potential & Blast $^{\circledR}$ \\
\hline $\begin{array}{l}\text { TLGSRTAGGCAT- } \\
\text { GLER }\end{array}$ & 1548.76 & 8.65 & 1 & 19.44 & ACE and DPP-IV inhibitory & $\begin{array}{c}\text { Arginine } \\
\text { decarboxylase }\end{array}$ \\
\hline TLHEPAGGTACLR & 1324.65 & 7.13 & 0 & 17.09 & $\begin{array}{l}\text { ACE, DPP-III, DDP-IV, and } \\
\text { renin inhibitory, antioxidant }\end{array}$ & Endochitinase 1 \\
\hline LTTASGGAGPFLF & 1237.63 & 5.52 & 0 & 7.53 & $\begin{array}{l}\text { ACE, DPP-III, DDP-IV, and } \\
\text { renin inhibitor, regulatory, } \\
\text { antiamnestic, } \\
\text { antithrombotic }\end{array}$ & $\begin{array}{l}\text { Casparian strip } \\
\text { membrane } \\
\text { protein } 1\end{array}$ \\
\hline NPGPSASGGGGATR & 1184.55 & 10.73 & 1 & 18.76 & $\begin{array}{l}\text { ACE and DPP-IV inhibitor, } \\
\text { regulatory, antiamnestic, } \\
\text { antithrombotic, chemotactic }\end{array}$ & $\begin{array}{l}21 \mathrm{kDa} \text { seed } \\
\text { protein }\end{array}$ \\
\hline TSVSGAGGPGAGR & 1072.52 & 10.73 & 1 & 17.31 & ACE and DPP-IV inhibitor & $\begin{array}{l}21 \text { kDa seed } \\
\text { protein }\end{array}$ \\
\hline LTGASPGGGAATV & 1057.53 & 5.58 & 0 & 13.39 & $\begin{array}{l}\text { ACE and DPP-IV inhibitor, } \\
\text { antioxidant, regulatory, } \\
\text { antiamnestic, } \\
\text { antithrombotic }\end{array}$ & $\begin{array}{l}\text { Casparian strip } \\
\text { membrane } \\
\text { protein } 1\end{array}$ \\
\hline TLGNPAAAGPF & 1014.51 & 5.32 & 0 & 10.12 & $\begin{array}{c}\text { ACE, DPP-III and DDP-IV } \\
\text { inhibitor, regulatory, } \\
\text { antiamnestic, } \\
\text { antithrombotic }\end{array}$ & $\begin{array}{l}\text { Casparian strip } \\
\text { membrane } \\
\text { protein } 1\end{array}$ \\
\hline
\end{tabular}


Table 2. Cont.

\begin{tabular}{|c|c|c|c|c|c|c|}
\hline Sequence & MW & Net Charge & $\begin{array}{l}\text { Isoelectric } \\
\text { Point }\end{array}$ & $\begin{array}{l}\text { Hydrophobicity } \\
\text { (Kcal/mol) }\end{array}$ & Biological Potential & Blast $^{\circledR}$ \\
\hline VSTSGAGTTAR & 1006.50 & 10.73 & 1 & 14.22 & ACE and DPP-IV inhibitor & $\begin{array}{l}21 \text { kDa seed } \\
\text { protein }\end{array}$ \\
\hline TRAGAGGGTVF & 992.50 & 10.9 & 1 & 13.64 & $\begin{array}{c}\text { ACE, DPP-IV, and CaMPDE } \\
\text { inhibitor, } \\
\text { ubiquitin-mediated } \\
\text { proteolysis activator }\end{array}$ & $\begin{array}{l}21 \text { kDa seed } \\
\text { protein }\end{array}$ \\
\hline LTADAGLGASL & 987.52 & 3.12 & -1 & 12.30 & $\begin{array}{l}\text { ACE, DPP-III, DDP-IV, and } \\
\alpha \text {-Glucosidase inhibitor }\end{array}$ & $\begin{array}{l}\text { Casparian strip } \\
\text { membrane } \\
\text { protein } 1\end{array}$ \\
\hline TTRGAAGAGGAV & 987.50 & 11.11 & 1 & 16.35 & $\begin{array}{l}\text { ACE, DPP-IV, and CaMPDE } \\
\text { inhibitor, antioxidant }\end{array}$ & $\begin{array}{l}21 \text { kDa seed } \\
\text { protein }\end{array}$ \\
\hline QTGGGGGGGGGGR & 973.43 & 10.73 & 1 & 22.23 & ACE and DPP-IV inhibitor & $\begin{array}{l}21 \text { kDa seed } \\
\text { protein }\end{array}$ \\
\hline TLSAGGAGPGGK & 971.50 & 9.8 & 1 & 17.05 & $\begin{array}{c}\text { ACE and DPP-IV inhibitor, } \\
\text { regulatory, antiamnestic, } \\
\text { antithrombotic }\end{array}$ & $\begin{array}{l}21 \text { kDa seed } \\
\text { protein }\end{array}$ \\
\hline THPAGGGGAAR & 950.46 & 10.73 & 1 & 18.53 & $\begin{array}{l}\text { ACE, DPP-III and DDP-IV } \\
\text { inhibitor, antioxidant }\end{array}$ & $\begin{array}{l}21 \text { kDa seed } \\
\text { protein }\end{array}$ \\
\hline TLSGGASGAAR & 946.48 & 10.73 & 1 & 14.58 & $\begin{array}{l}\text { ACE and DPP-IV inhibitor, } \\
\text { antioxidant }\end{array}$ & $\begin{array}{l}\text { Casparian strip } \\
\text { membrane } \\
\text { protein } 1\end{array}$ \\
\hline KMTGVVAW & 890.46 & 9.98 & 1 & 8.92 & $\begin{array}{l}\text { ACE, and DPP-IV inhibitor, } \\
\text { antioxidant }\end{array}$ & Endochitinase 1 \\
\hline LTTAGAAKF & 878.48 & 9.93 & 1 & 10.89 & $\begin{array}{l}\text { ACE, DPP-IV, renin, and } \\
\text { CaMPDE inhibitor, } \\
\text { antioxidant }\end{array}$ & $\begin{array}{l}\text { Casparian strip } \\
\text { membrane } \\
\text { protein } 1\end{array}$ \\
\hline KGGPSGATGK & 858.45 & 10.57 & 2 & 19.45 & $\begin{array}{c}\text { ACE and DPP-IV inhibitor, } \\
\text { regulatory, antiamnestic, } \\
\text { antithrombotic }\end{array}$ & $\begin{array}{c}\text { Arginine } \\
\text { decarboxylase }\end{array}$ \\
\hline VPDGLASV & 756.40 & 3.15 & -1 & 11.62 & $\begin{array}{c}\text { ACE, DPP-III, and DPP-IV } \\
\text { inhibitory, } \\
\text { ubiquitin-mediated } \\
\text { proteolysis activator }\end{array}$ & $\begin{array}{c}\text { Arginine } \\
\text { decarboxylase }\end{array}$ \\
\hline SPPSGAGL & 684.34 & 5.45 & 0 & 10.65 & $\begin{array}{c}\text { ACE, DPP-IV, and } \\
\alpha \text {-Glucosidase inhibitor }\end{array}$ & $\begin{array}{l}21 \text { kDa seed } \\
\text { protein }\end{array}$ \\
\hline SNAGGGGGP & 672.28 & 5.49 & 0 & 15.60 & $\begin{array}{c}\text { ACE and DPP-IV inhibitor, } \\
\text { regulatory, antiamnestic, } \\
\text { antithrombotic }\end{array}$ & $\begin{array}{l}21 \text { kDa seed } \\
\text { protein }\end{array}$ \\
\hline LSPGGAAV & 670.36 & 5.58 & 0 & 10.09 & $\begin{array}{c}\text { ACE and DPP-IV inhibitor, } \\
\text { antioxidant, antiamnestic, } \\
\text { antithrombotic }\end{array}$ & Vicilin \\
\hline TTKGGSGVF & 852.43 & 9.93 & 1 & 12.94 & ACE and DPP-IV inhibitor & Maturase K \\
\hline SPALNPG & 654.33 & 5.46 & 0 & 9.89 & $\begin{array}{c}\text { ACE and DPP-IV inhibitor, } \\
\text { regulatory, antiamnestic, } \\
\text { antithrombotic }\end{array}$ & Endochitinase 1 \\
\hline SLTASAV & 647.34 & 5.45 & 0 & 8.36 & ACE and DPP-IV inhibitor & $\begin{array}{l}21 \text { kDa seed } \\
\text { protein }\end{array}$ \\
\hline LTSAAV & 560.31 & 5.58 & 0 & 7.90 & ACE and DPP-IV inhibitor & $\begin{array}{l}\text { Casparian strip } \\
\text { membrane } \\
\text { protein } 1\end{array}$ \\
\hline
\end{tabular}

ACE: angiotensin converting enzyme; DPP-III: dipeptidyl peptidase III; DPP-IV: dipeptidyl peptidase IV; Blast ${ }^{\circledR}$ : https: / /blast.ncbi.nlm. nih.gov/Blast.cgi?PROGRAM=blastp\&PAGE_TYPE=BlastSearch\&LINK_LOC=blasthome (accessed on 24 March 2021).

\subsection{Inhibitory Effect of Cocoa Peptides on RAS Enzymes by In Silico and In Vitro Analysis}

The bioinformatics analysis by the BIOPEP-UWM database showed possible effects to control hypertension through ACE and renin inhibition. The results of the theoretical affinity of the peptides with the three molecular targets related to hypertension are shown in Table 3. The peptide with the highest theoretical affinity for ACE was SNAGGGGGP, with a value of $-9.1 \mathrm{kcal} / \mathrm{mol}$, higher than that shown by the drug Lisinopril $(-7.7 \mathrm{kcal} / \mathrm{mol})$. The potential interactions of this peptide with ACE involved seven conventional hydrogen bonds with the residues $\mathrm{N}_{415}, \mathrm{~N}_{277}, \mathrm{Q}_{208}, \mathrm{~K}_{511}, \mathrm{~T}_{282}, \mathrm{D}_{453}$, and $\mathrm{Y}_{394}$, starting with the nitrogen of $S^{1}$ and ending with the carbonyl of the carboxyl group in $\mathrm{P}^{9}$, four carbon- 
hydrogen bonds (amino acid residues $\mathrm{H}_{513}, \mathrm{E}_{384}, \mathrm{~A}_{354}$, and $\mathrm{A}_{356}$ ) from the carbonyl of $\mathrm{G}^{4}$ to the pyrrolidine ring of $\mathrm{P}^{9}$, two unfavorable donor-donor links (amino acid residues $\mathrm{Y}_{523}$ and $\mathrm{H}_{387}$ ), a pi-donating hydrogen double bond with hydrogen of an $\mathrm{N}^{2}$, and finally a pi-alkyl bond between the residue $\mathrm{F}_{391}$ with the pyrrolidine ring of proline ${ }^{9}$ (Figure 2A). Peptide SNAGGGGGP also showed the highest affinity to interact with renin $(-3.9 \mathrm{kcal} / \mathrm{mol})$, in comparison with other peptides identified in Criollo cocoa although lower to that shown by the drug Aliskiren $(-7.8 \mathrm{kcal} / \mathrm{mol})$. The interaction with peptide SNAGGGGGP implied seven conventional hydrogen bonds and two carbon bonds with the $T_{12}$ residue and the first $\mathrm{S}^{1}$ carbon (Figure $2 \mathrm{~B}$ ). The Criollo cocoa peptides showed potent interaction with the $\mathrm{AT}_{1}-\mathrm{R}$, having 13 of them higher affinity compared with the drug Losartan $(-8.3 \mathrm{kcal} / \mathrm{mol}$, Table 3). The highest values were obtained for peptides TLGNPAAAGPF (Figure 2C).

Table 3. Molecular docking of Criollo cocoa peptides on molecular targets related to hypertension.

\begin{tabular}{|c|c|c|c|}
\hline \multirow{3}{*}{ Sequence } & \multicolumn{3}{|c|}{ Docking Molecular } \\
\hline & \multicolumn{3}{|c|}{ Affinity (kcal/mol) } \\
\hline & ACE-1 & Renin & $\mathrm{AT}_{1}-\mathrm{R}$ \\
\hline TLGSRTAGGCATGLER & -5.7 & -2.4 & -8.8 \\
\hline TLHEPAGGTACLR & -6.9 & -2.4 & -7.6 \\
\hline LTTASGGAGPFLF & -6.1 & -2.5 & -9.5 \\
\hline NPGPSASGGGGATR & -6.6 & -2.9 & -8.5 \\
\hline TSVSGAGGPGAGR & -1.6 & -3.0 & ND \\
\hline LTGASPGGGAATV & -5.8 & -2.8 & -10 \\
\hline TLGNPAAAGPF & -7.2 & -3.3 & -10.2 \\
\hline VSTSGAGTTAR & -6.5 & -3.0 & -9.4 \\
\hline TRAGAGGGTVF & -6.9 & -3.3 & -9.8 \\
\hline LTADAGLGASL & -6.4 & -3.5 & -9.3 \\
\hline TTRGAAGAGGAV & -6.4 & -3.8 & -9.1 \\
\hline QTGGGGGGGGGGR & -6.6 & -2.7 & -7.9 \\
\hline TLSAGGAGPGGK & -6.1 & -2.4 & -8.4 \\
\hline THPAGGGGAAR & -6.7 & -3.2 & -8.3 \\
\hline TLSGGASGAAR & -5.8 & -2.1 & -8.3 \\
\hline KMTGVVAW & -6.5 & -3.4 & -9.0 \\
\hline LTTAGAAKF & -5.4 & -2.5 & -8.3 \\
\hline KGGPSGATGK & -5.3 & -2.8 & -8.1 \\
\hline TTKGGSGVF & -5.5 & -2.2 & -8.4 \\
\hline VPDGLASV & -6.6 & -4.0 & -8.9 \\
\hline SPPSGAGL & -7.6 & -3.3 & -8.2 \\
\hline SNAGGGGGP & 9.1 & -3.9 & -7.8 \\
\hline LSPGGAAV & -8.6 & -3.2 & -8.5 \\
\hline SPALNPG & -6.8 & -4.0 & -9.0 \\
\hline SLTASAV & -6.3 & -3.9 & -8.1 \\
\hline LTSAAV & -5.2 & -3.1 & -7.0 \\
\hline Lisopril & -7.7 & - & - \\
\hline Aliskiren & - & -7.8 & - \\
\hline Losartan & - & - & -8.3 \\
\hline
\end{tabular}

ACE: Angiotensin converting enzyme. ND: Not docking. LTGASPGGGAATV, TRAGAGGGTVF, LTTASGGAGPFLF, and VSTSGAGTTAR with affinity values of $-10.2,-10$, $-9.8,-9.5$, and $-9.4 \mathrm{kcal} / \mathrm{mol}$, respectively. Confirmation of the ACE inhibitory activity was performed by an in vitro analysis, obtaining an $\mathrm{IC}_{50}$ value of $0.49 \mathrm{mg}$ of $\mathrm{CPH} / \mathrm{mL}$.

\subsection{Effects of Cocoa Peptides on Blood Pressure}

The effects of cocoa peptides on the blood pressure were evaluated using an obesityinduced by diet rat model. SBP, DBP, MBP, and HR were measured in the rats of the different groups at the beginning of the study and after 8 weeks of treatment. As shown in Figure $3 \mathrm{~A}-\mathrm{C}$, the intake of a HF diet significantly $(p<0.001)$ increased SBP, DBP, and MBP. However, the oral administration of $\mathrm{CP}(\mathrm{CP}+\mathrm{HF}$ group) reverted these effects, and the blood pressure significantly decreased. No effects of $\mathrm{CP}$ on the HR were observed, being 
similar in HF and CP + HF groups at the end of the assay. Only the animals fed STD diet group showed a decrease of HR levels after 8 weeks (Figure 3D).

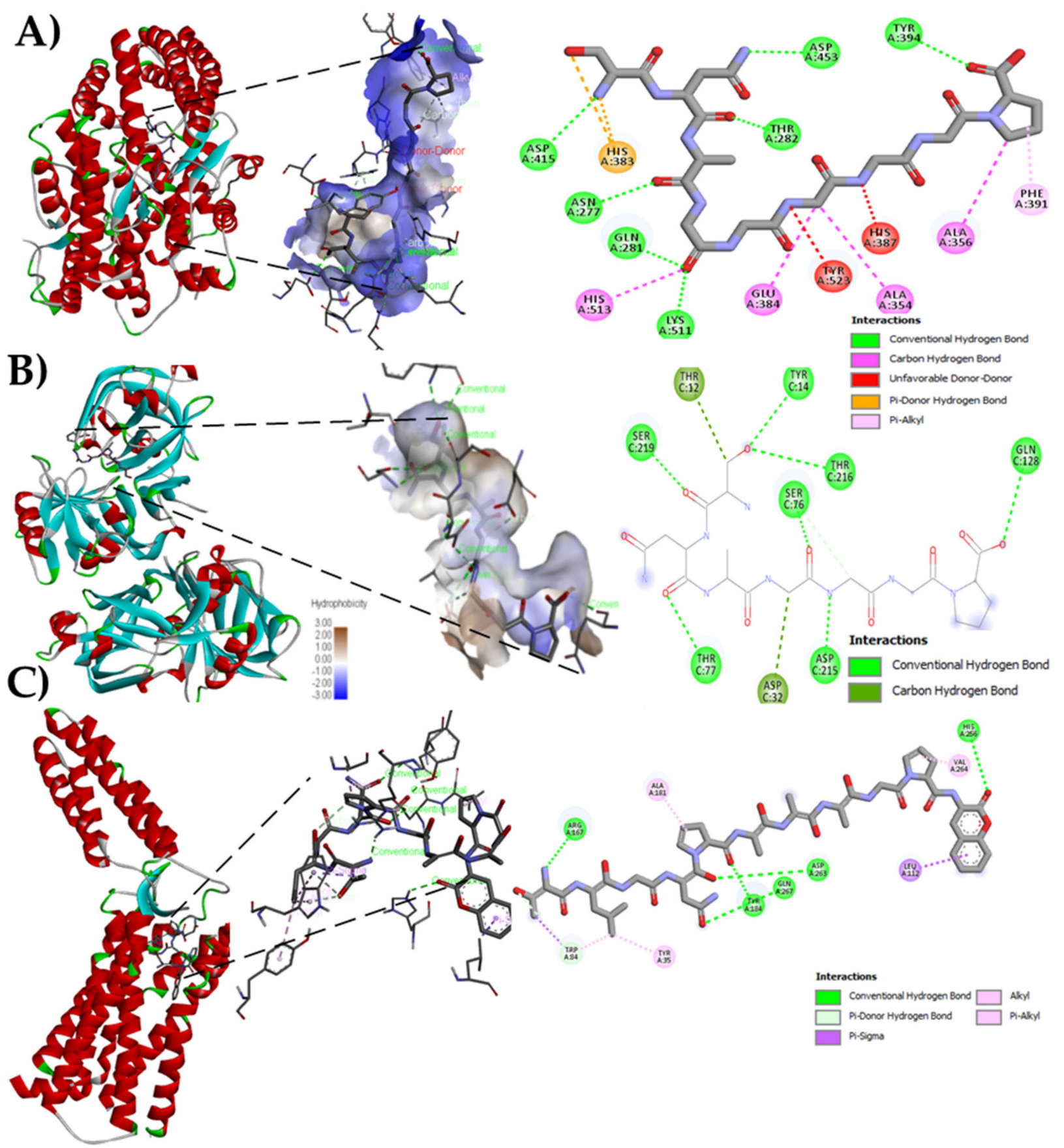

Figure 2. Molecular docking of native criollo peptides. (A) Molecular docking of peptide SNAGGGGGP with the Angiotensin Converting Enzyme (ACE) (PDB: ID 1086); (B) Molecular docking of peptide SNAGGGGGP with Renin (PDB: ID 2V0Z); (C) Molecular docking of peptide TLGNPAAAGPF with $\mathrm{AT}_{1}-\mathrm{R}$ (PDB: ID 4YAY). 

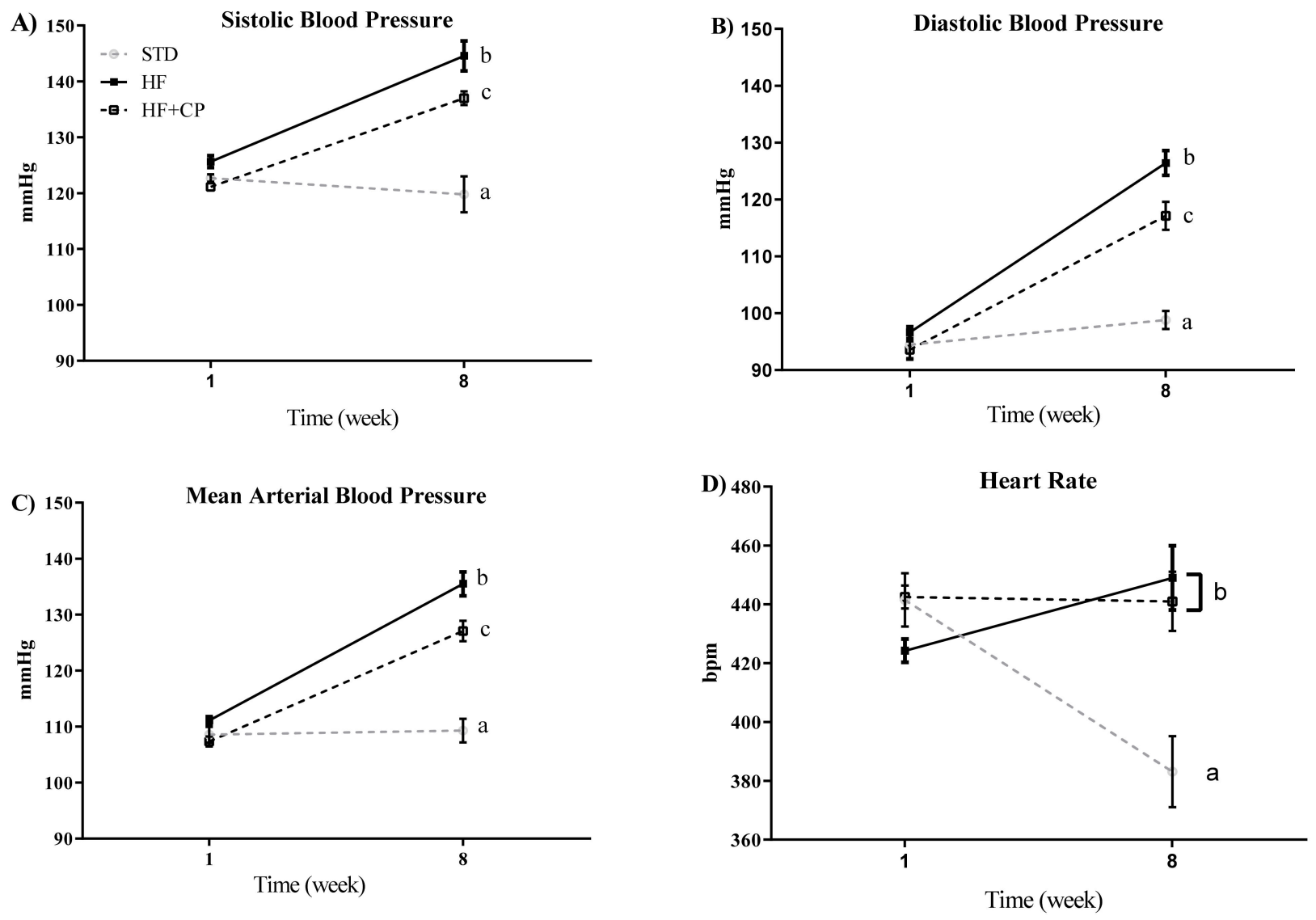

Figure 3. Effect of cocoa protein on blood pressure and heart rate in an obesity-induced by diet rat model. (A) Systolic blood pressure (SBP), (B) diastolic blood pressure (DBP), (C) mean blood pressure (MBP), and (D) heart rate (HR) measured by tail-cuff plethysmography at times 0 and 8 weeks. Values are expressed as mean \pm SEM ( $n=7$ per group). ${ }^{a, b, c}$ significantly different from STD, HF and HF + CP groups, respectively $(p<0.001)$.

\section{Discussion}

In the in silico study, the affinity of Criollo cocoa peptides for hypertension-related molecular targets $\mathrm{ACE}$, renin, and $\mathrm{AT}_{1}-\mathrm{R}$ has been demonstrated. The peptide sequences obtained from Criollo CP showed several potential biological activities. According to the BIOPEP-UWM database, the potential ACE and DPP-IV inhibitory capacity, which are related to hypertension and type 2 diabetes was outstanding. Similar data were found for other vegetable proteins such as concanavalin A, B, and Canavalia from the Indonesian Jack bean (Canavalia ensiformis), which contained mainly ACE and DPP-IV inhibitory peptides and in a lesser extent, sequences with antithrombotic and stimulating activity [39]. In Amaranthus hypochondriacus (amaranth), many peptides with the potential to inhibit ACE were found [40], as it was also demonstrated for $\alpha$ and $\beta$ subunits of chickpea (Cicer arietinum L.) that contained 177 and $133 \mathrm{ACE}$ inhibitory peptide sequences, respectively [41]. Proteins from animal sources such as alpha-actin from tilapia (Oreochromis spp.) were also reported to contain bioactive peptides. Among them, 146 peptides were found to exert ACE inhibitory activity and 16 peptides demonstrated potential as antioxidants [42].

The analysis by molecular docking of the Criollo cocoa peptides showed their high affinity for $\mathrm{ACE}$, renin, and $\mathrm{AT}_{1}-\mathrm{R}$. These three molecular targets are the main responsible for hypertension, cardiovascular disease, and mortality [43]. Similar affinity has been previously described for peptides derived from chia proteins which sequences were TAQEPTIRF, PGLTIGDTIPNL, LSLPNYHPNPRL, LIVSPLAGRL, and IVSPLAGRL [44].

The peptides derived from Phaseolus vulgaris L. proteins, which sequences were GLTSK and GEGSGA, also showed a good affinity for $\mathrm{ACE}$, renin, and $\mathrm{AT}_{1}-\mathrm{R}$ [45]. Similar results were found for peptides WG and PRY contained in potato proteins [46]. These results 
suggest an inhibitory effect of plant proteins derived peptides on the RAS function, thus acting reducing the hypertensive state. The in vitro analysis confirmed this potential as CPH showed ACE inhibitory ability. Similar results were observed for other vegetable proteins, such as hydrolyzed kiwicha (Amaranthus caudatus), and quinoa (Chenopodium quinoa) [47]. $\mathrm{IC}_{50}$ values of $\mathrm{CPH}$ were similar to those reported for camel whey protein hydrolyzates [48].

In the in vivo model, intragastric administration of $\mathrm{CP}$ in rats fed HF diet effectively lowered SBP and DBP over eight weeks of treatment. During the testing of new oral drugs, the translation of doses among animal species is essential. In this study, the key HED was obtained to translate the dose of CP from animals to humans based on the BSA. This value is used because its relationship with various biological parameters, including oxygen utilization, circulating plasma proteins, caloric expenditure, basal metabolism, blood volume, and renal function in several mammalian species. Therefore, the HED equation is recommended for converting doses from animals to humans, especially for phase I and phase II clinical trials [49]. The HED for $150 \mathrm{mg} \mathrm{CP} / \mathrm{kg} /$ day for an adult $(60 \mathrm{~kg})$ is $1.46 \mathrm{~g}$. To date, no data about the potential of CP to reduce blood pressure were available. Previous studies had described the blood pressure reduction with the intragastric administration of other food proteins such as Amaranth protein hydrolyzates in spontaneously hypertensive rats [13]. More recently, a study was carried out with cookies enriched with bioactive Amaranth protein hydrolysates confirmed that the baking process and the matrix of the cookies did not alter the antihypertensive effect [50]. Bean protein hydrolysate was also demonstrated to exert SBP and DBP reducing effects at doses of $20 \mathrm{mg} / \mathrm{kg}$ body weight [51].

\section{Conclusions}

In the present study, the effect of the peptides derived from cocoa proteins against molecular targets related to high blood pressure was demonstrated by both in silico and in vitro tests. Moreover, an animal model of obesity-induced arterial hypertension was conducted to confirm the anti-hypertensive activity, demonstrating that the consumption of cocoa proteins resulted in a decrease of both SBP and DBP. Altogether, all results suggest the promising value of $\mathrm{CP}$ as a novel ingredient for functional foods or nutraceuticals to prevent/manage chronic disorders associated with hypertension and/or obesity. However, the translation of dose from animals to humans and the confirmation of these beneficial effects in human trials should be needed.

Author Contributions: Conceptualization, E.L.C. and G.R.-C.; Methodology, L.J.C.-C., G.R.-C., L.Q.-C. and L.M.; Writing-Original Draft Preparation, L.J.C.-C. and E.L.C.; Writing-Review and Editing, G.R.-C., L.M., G.A.C.-H. and B.H.-L.; Supervision, E.L.C., G.R.-C. and L.Q.-C.; Project Administration, E.L.C. and B.H.-L.; Funding Acquisition, E.L.C., B.H.-L. and L.Q.-C. All authors have read and agreed to the published version of the manuscript.

Funding: This study was funded by projects 2017-02-291417 “Development of technological innovations for the sustainable integrated management of the Cocoa crop (Theobroma cacao L.) in Mexico" (CONACYT-SAGARPA), PID2019-104218RB-I00/AEI/2015-66886R (Ministry of Science and, Innovation, Spain), and SIP20195713 (Instituto Politécnico Nacional, IPN).

Institutional Review Board Statement: Not applicable.

Informed Consent Statement: Not applicable.

Data Availability Statement: Not applicable.

Conflicts of Interest: The authors declare no conflict of interest.

\section{References}

1. Rawel, H.M.; Huschek, G.; Sagu, S.T.; Homann, T. Cocoa bean proteins-Characterization, changes and modifications due to ripening and post-harvest processing. Nutrients 2019, 11, 428. [CrossRef] 
2. Naghavi, M.; Abajobir, A.A.; Abbafati, C.; Abbas, K.M.; Abd-Allah, F.; Abera, S.F.; Aboyans, V.; Adetokunboh, O.; Afshin, A.; Agrawal, A.; et al. Global, regional, and national age-sex specific mortality for 264 causes of death, 1980-2016: A systematic analysis for the Global Burden of Disease Study 2016. Lancet 2017, 390, 1151-1210. [CrossRef]

3. Egan, B.M.; Kjeldsen, S.E.; Grassi, G.; Esler, M.; Mancia, G. The global burden of hypertension exceeds 1.4 billion people. J. Hypertens. 2019, 37, 1148-1153. [CrossRef]

4. Mills, K.T.; Stefanescu, A.; He, J. The global epidemiology of hypertension. Nat. Rev. Nephrol. 2020, 16, 223-237. [CrossRef] [PubMed]

5. Acharya, K.R.; Sturrock, E.D.; Riordan, J.F.; Ehlers, M.R.W. Ace revisited: A new target for structure-based drug design. Nat. Rev. Drug Discov. 2003, 2, 891-902. [CrossRef]

6. Lin, L.; Lv, S.; Li, B. Angiotensin-I-converting enzyme (ACE)-inhibitory and antihypertensive properties of squid skin gelatin hydrolysates. Food Chem. 2012, 131, 225-230. [CrossRef]

7. Hou, F.F.; Zhang, X.; Zhang, G.H.; Xie, D.; Chen, P.Y.; Zhang, W.R.; Jiang, J.P.; Liang, M.; Wang, G.B.; Liu, Z.R.; et al. Efficacy and Safety of Benazepril for Advanced Chronic Renal Insufficiency. N. Engl. J. Med. 2006, 354, 131-140. [CrossRef]

8. Evangelista, S.; Manzini, S. Antioxidant and Cardioprotective Properties of the Sulphydryl Angiotensinconverting Enzyme Inhibitor Zofenopril. J. Int. Med. Res. 2005, 33, 42-54. [CrossRef] [PubMed]

9. Brown, N.J.; Vaughan, D.E. Angiotensin-Converting Enzyme Inhibitors. Circulation 1998, 97, 1411-1420. [CrossRef] [PubMed]

10. Aluko, R.E. Food protein-derived renin-inhibitory peptides: In vitro and in vivo properties. J. Food Biochem. 2019, 43, e12648. [CrossRef]

11. Aluko, R.E. Antihypertensive Peptides from Food Proteins. Annu. Rev. Food Sci. Technol. 2015, 6, 235-262. [CrossRef]

12. Valverde, M.E.; Orona-Tamayo, D.; Nieto-Rendón, B.; Paredes-López, O. Antioxidant and Antihypertensive Potential of Protein Fractions from Flour and Milk Substitutes from Canary Seeds (Phalaris canariensis L.). Plant Foods Hum. Nutr. 2017, $72,20-25$. [CrossRef] [PubMed]

13. Ramírez-Torres, G.; Ontiveros, N.; Lopez-Teros, V.; Ibarra-DIarte, J.A.; Reyes-Moreno, C.; Cuevas-Rodríguez, E.O.; CabreraChávez, F. Amaranth protein hydrolysates efficiently reduce systolic blood pressure in spontaneously hypertensive rats. Molecules 2017, 22, 1905. [CrossRef] [PubMed]

14. Motamayor, J.C.; Moreno, A.; Lanaud, C.; Lopez, P.A.; Ortiz, C.F.; Risterucci, A.M. Cacao domestication I: The origin of the cacao cultivated by the Mayas. Heredity 2002, 89, 380-386. [CrossRef] [PubMed]

15. Laliberte, B. A Global Strategy for the Conservation and Use of Cacao Genetic Resources, as the Foundation for a Sustainable Cocoa Economy; Bioversity International: Montpellier, France, 2012; pp. 1-186.

16. Actis-Goretta, L.; Ottaviani, J.I.; Keen, C.L.; Fraga, C.G. Inhibition of angiotensin converting enzyme (ACE) activity by flavan-3-ols and procyanidins. FEBS Lett. 2003, 555, 597-600. [CrossRef]

17. Engler, M.B.; Engler, M.M. The Emerging Role of Flavonoid-Rich Cocoa and Chocolate in Cardiovascular Health and Disease. Nutr. Rev. 2006, 64, 109-118. [CrossRef]

18. Rabadán-Chávez, G.M.; Reyes-Maldonado, E.; Quevedo-Corona, L.; Paniagua-Castro, N.; Escalona-Cardoso, G.; Jaramillo-Flores, M.E. The prothrombotic state associated with obesity-induced hypertension is reduced by cocoa and its main flavanols. Food Funct. 2016, 7, 4880-4888. [CrossRef] [PubMed]

19. Sarmadi, B.; Ismail, A.; Hamid, M. Antioxidant and angiotensin converting enzyme (ACE) inhibitory activities of cocoa (Theobroma cacao L.) autolysates. Food Res. Int. 2011, 44, 290-296. [CrossRef]

20. Coronado-cáceres, L.J.; Rabadán-chávez, G.; Quevedo-corona, L.; Hernández-ledesma, B.; Miliar, A.; Mojica, L.; Lugo-cervantes, E. Anti-obesity effect of cocoa proteins (Theobroma cacao L.) variety "Criollo" and the expression of genes related to the dysfunction of white adipose tissue in high-fat diet-induced obese rats. J. Funct. Foods 2019, 62, 103519. [CrossRef]

21. Voigt, J.; Biehl, B.; Wazir, S.K.S. The major seed proteins of Theobroma cacao L. Food Chem. 1993, 47, 145-151. [CrossRef]

22. Preza, A.M.; Jaramillo, M.E.; Puebla, A.M.; Mateos, J.C.; Hernández, R.; Lugo, E. Antitumor activity against murine lymphoma L5178Y model of proteins from cacao (Theobroma cacao L.) seeds in relation with in vitro antioxidant activity. BMC Complement. Altern. Med. 2010, 10, 61. [CrossRef] [PubMed]

23. Lowry, O.; Rosebrough, N.; Farr, A.L.; Randall, R. Protein Measurement with the Folin Phenol Reagent. J. Biol. Chem. 1951, 193, 265-275. [CrossRef]

24. Laemmli, U.K. Cleavage of Structural Proteins during the Assembly of the Head of Bacteriophage T4. Nature 1970, 227, 680-685. [CrossRef]

25. Mojica, L.; Chen, K.; de Mejía, E.G. Impact of Commercial Precooking of Common Bean (Phaseolus vulgaris) on the Generation of Peptides, After Pepsin-Pancreatin Hydrolysis, Capable to Inhibit Dipeptidyl Peptidase-IV. J. Food Sci. 2015, 80, H188-H198. [CrossRef]

26. De Souza Rocha, T.; Hernandez, L.M.R.; Chang, Y.K.; de Mejía, E.G. Impact of germination and enzymatic hydrolysis of cowpea bean (Vigna unguiculata) on the generation of peptides capable of inhibiting dipeptidyl peptidase IV. Food Res. Int. 2014, 64, 799-809. [CrossRef]

27. Burley, S.K.; Berman, H.M.; Christie, C.; Duarte, J.M.; Feng, Z.; Westbrook, J.; Young, J.; Zardecki, C. RCSB Protein Data Bank: Sustaining a living digital data resource that enables breakthroughs in scientific research and biomedical education. Protein Sci. 2018, 27, 316-330. [CrossRef] 
28. Minkiewicz, P.; Iwaniak, A.; Darewicz, M. BIOPEP-UWM database of bioactive peptides: Current opportunities. Int. J. Mol. Sci. 2019, 20, 5978. [CrossRef] [PubMed]

29. Natesh, R.; Schwager, S.L.U.; Sturrock, E.D.; Acharya, K.R. Crystal structure of the human enzyme-lisinopril complex. Nature 2003, 421, 1427-1429. [CrossRef]

30. Pan, D.; Cao, J.; Guo, H.; Zhao, B. Studies on purification and the molecular mechanism of a novel ACE inhibitory peptide from whey protein hydrolysate. Food Chem. 2012, 130, 121-126. [CrossRef]

31. Trott, O.; Olson, A.J. AutoDock Vina: Improving the speed and accuracy of docking with a new scoring function, efficient optimization, and multithreading. J. Comput. Chem. 2009, 32, 455-461. [CrossRef]

32. Díaz-Gómez, J.L.; Neundorf, I.; López-Castillo, L.M.; Castorena-Torres, F.; Serna-Saldívar, S.O.; García-Lara, S. In Silico Analysis and In Vitro Characterization of the Bioactive Profile of Three Novel Peptides Identified from $19 \mathrm{kDa} \alpha$-Zein Sequences of Maize. Molecules 2020, 25, 5405. [CrossRef] [PubMed]

33. De Alvarenga, E.C.; De Castro Fonseca, M.; Carvalho, C.C.; Florentino, R.M.; França, A.; Matias, E.; Guimarães, P.B.; Batista, C.; Freire, V.; Carmona, A.K.; et al. Angiotensin converting enzyme regulates cell proliferation and migration. PLoS ONE 2016, 11, e0165371. [CrossRef] [PubMed]

34. Alcaide-Hidalgo, J.M.; Margalef, M.; Bravo, F.I.; Muguerza, B.; López-Huertas, E. Virgin olive oil (unfiltered) extract contains peptides and possesses ACE inhibitory and antihypertensive activity. Clin. Nutr. 2020, 39, 1242-1249. [CrossRef] [PubMed]

35. Coronado-Cáceres, L.J.; Rabadán-Chávez, G.; Mojica, L.; Hernández-Ledesma, B.; Quevedo-Corona, L.; Cervantes, E.L. Cocoa seed proteins' (Theobroma cacao L.) anti-obesity potential through lipase inhibition using in silico, in vitro and in vivo models. Foods 2020, 9, 1359. [CrossRef] [PubMed]

36. Grasa-López, A.; Miliar-García, Á.; Quevedo-Corona, L.; Paniagua-Castro, N.; Escalona-Cardoso, G.; Reyes-Maldonado, E.; Jaramillo-Flores, M.-E. Undaria pinnatifida and Fucoxanthin Ameliorate Lipogenesis and Markers of Both Inflammation and Cardiovascular Dysfunction in an Animal Model of Diet-Induced Obesity. Mar. Drugs 2016, 14, 148. [CrossRef] [PubMed]

37. Perry, C.M. Azilsartan medoxomil: A review of its use in hypertension. Clin. Drug Investig. 2012, 32, 621-639. [CrossRef]

38. Services, H. Guidance for Industry: Characterization and Qualification of Cell Substrates and Other Biological Starting Materials Used in the Production of Viral Vaccines for the Prevention and Treatment of Infectious Diseases. Biotechnol. Law Rep. 2006, 25, 697-723. [CrossRef]

39. Zulvana, A.H.; Andriati, N.; Sri, A.; Widiastuti, S. In silico approach in evaluation of jack bean (Canavalia ensiformis) canavalin protein as precursors of bioactive peptides with dual antioxidant and angiotensin i-converting enzyme inhibitor. Mater. Sci. Forum 2019, 948, 85-94. [CrossRef]

40. Montoya-Rodríguez, A.; Gómez-Favela, M.A.; Reyes-Moreno, C.; Milán-Carrillo, J.; González de Mejía, E. Identification of bioactive peptide sequences from amaranth (amaranthus hypochondriacus) seed proteins and their potential role in the prevention of chronic diseases. Compr. Rev. Food Sci. Food Saf. 2015, 14, 139-158. [CrossRef]

41. Chang, Y.W.; Alli, I. In silico assessment: Suggested homology of chickpea (Cicer arietinum L.) legumin and prediction of ACE-inhibitory peptides from chickpea proteins using BLAST and BIOPEP analyses. Food Res. Int. 2012, 49, 477-486. [CrossRef]

42. Huang, B.B.; Lin, H.C.; Chang, Y.W. Analysis of proteins and potential bioactive peptides from tilapia (Oreochromis spp.) processing co-products using proteomic techniques coupled with BIOPEP database. J. Funct. Foods 2015, 19, 629-640. [CrossRef]

43. Wang, C.; Yuan, Y.; Zheng, M.; Pan, A.; Wang, M.; Zhao, M.; Li, Y.; Yao, S.; Chen, S.; Wu, S.; et al. Association of Age of Onset of Hypertension With Cardiovascular Diseases and Mortality. J. Am. Coll. Cardiol. 2020, 75, 2921-2930. [CrossRef]

44. San Pablo-Osorio, B.; Mojica, L.; Urías-Silvas, J.E. Chia Seed (Salvia hispanica L.) Pepsin Hydrolysates Inhibit AngiotensinConverting Enzyme by Interacting with its Catalytic Site. J. Food Sci. 2019, 84, 1170-1179. [CrossRef]

45. Luna-Vital, D.A.; Liang, K.; De Mejía, E.G.; Loarca-Piña, G. Dietary peptides from the non-digestible fraction of: Phaseolus vulgaris L. decrease angiotensin II-dependent proliferation in HCT116 human colorectal cancer cells through the blockade of the renin-angiotensin system. Food Funct. 2016, 7, 2409-2419. [CrossRef] [PubMed]

46. Fu, Y.; Alashi, A.M.; Young, J.F.; Therkildsen, M.; Aluko, R.E. Enzyme inhibition kinetics and molecular interactions of patatin peptides with angiotensin I-converting enzyme and renin. Int. J. Biol. Macromol. 2017, 101, 207-213. [CrossRef]

47. Chirinos, R.; Pedreschi, R.; Velásquez-Sánchez, M.; Aguilar-Galvez, A.; Campos, D. In vitro antioxidant and angiotensin Iconverting enzyme inhibitory properties of enzymatically hydrolyzed quinoa (Chenopodium quinoa) and kiwicha (Amaranthus caudatus) proteins. Cereal Chem. 2020, 97, 949-957. [CrossRef]

48. Osman, A.; El-Hadary, A.; Korish, A.A.; AlNafea, H.M.; Alhakbany, M.A.; Awad, A.A.; Abdel-Hamid, M. Angiotensin-I converting enzyme inhibition and antioxidant activity of papain-hydrolyzed camel whey protein and its hepato-renal protective effects in thioacetamide-induced toxicity. Foods 2021, 10, 468. [CrossRef] [PubMed]

49. Reagan-Shaw, S.; Nihal, M.; Ahmad, N. Dose translation from animal to human studies revisited. FASEB J. 2008, $22,659-661$. [CrossRef] [PubMed]

50. Ontiveros, N.; López-Teros, V.; de Jesús Vergara-Jiménez, M.; Islas-Rubio, A.R.; Cárdenas-Torres, F.I.; Cuevas-Rodríguez, E.O.; Reyes-Moreno, C.; Granda-Restrepo, D.M.; Lopera-Cardona, S.; Ramírez-Torres, G.I.; et al. Amaranth-hydrolyzate enriched cookies reduce the systolic blood pressure in spontaneously hypertensive rats. J. Funct. Foods 2020, 64, 103613. [CrossRef]

51. Sonklin, C.; Alashi, M.A.; Laohakunjit, N.; Kerdchoechuen, O.; Aluko, R.E. Identification of antihypertensive peptides from mung bean protein hydrolysate and their effects in spontaneously hypertensive rats. J. Funct. Foods 2020, 64, 103635. [CrossRef] 